\title{
Analisis Faktor yang Mempengaruhi Kesadaran Penduduk dalam Vaksin Covid-19 Menggunakan Metode Multivariate Adaptive Regression Spline
}

Ninda Rizkya Shafana*, Gani Gunawan

Prodi Matematika, Fakultas Matematika dan Ilmu Pengetahuan Alam, Universitas Islam Bandung, Indonesia.

*nindarshafana@gmail.com,ggani9905@gmail.com

\begin{abstract}
The purpose of this study was to find out what factors influence public awareness of the Covid-19 vaccine in Sumedang Regency. Sumedang Regency was chosen as the research location because it is one of the areas in West Java with the highest immunization rate. This attracted the attention of researchers, prompting them to conduct a study using the Multivariate Adaptive Regression Spline (MARS) method to determine the elements that influence vaccination awareness of the local population. This study uses secondary data from the population of Sumedang Regency who has carried out the Covid-19 vaccine on September 28, 2021. Before performing the MARS analysis, the researcher used normality, heteroscedasticity, and autocorrelation tests to validate the assumptions of the regression model. The findings reveal that categories, doses, types of vaccines, and age variables are predictor variables that affect public awareness of the Covid-19 vaccine.
\end{abstract}

Keywords: factor analysis, Multivariate Adaptive Regression Spline, Covid-19 vaccine.

Abstrak. Penelitian ini bertujuan untuk mengetahui faktor-faktor yang memengaruhi kesadaran penduduk dalam melakukan vaksin Covid-19 di Kabupaten Sumedang. Peneliti memilih Kabupaten Sumedang sebagai lokasi penelitian, dimana kabupaten ini merupakan salah satu kabupaten di Jawa Barat yang memiliki tingkat vaksinasi tertinggi. Hal ini menarik perhatian peneliti untuk melakukan penelitian dalam mengetahui faktor-faktor yang dapat mempengaruhi kesadaran penduduk setempat untuk melakukan vaksinasi dengan metode Multivariate Adaptive Regression Spline (MARS). Penelitian ini menggunakan data sekunder penduduk Kabupaten Sumedang yang telah melakukan vaksin Covid-19 pada tanggal 28 September 2021. Sebelum dilakukan analisis menggunakan metode MARS, peneliti melakukan pengujian asumsi model regresi terlebih dahulu melalui uji normalitas, uji hetesrokedastisitas, serta uji autokorelasi. Hasil penelitian menunjukkan bahwa variabel prediktor yang berpengaruh terhadap kesadaran penduduk dalam melakukan vaksin Covid-19 adalah variabel kategori, dosis, jenis vaksin, dan variabel usia.

Kata Kunci: analisis faktor, Multivariate Adaptive Regression Spline, vaksin Covid-19. 


\section{A. Pendahuluan}

Pandemi Covid-19, yang telah menyebar hampir ke seluruh dunia, tampaknya terus berlanjut dan terus menjadi ancaman bagi masyarakat global. Melihat dari masih tingginya kasus positif Covid-19 baik di Indonesia maupun di dunia membuat pemerintah Indonesia terus mengupayakan untuk terus melakukan usaha-usaha pencegahan dan pemutusan rantai penyebaran virus Covid-19. Pemerintah terus mengedukasi masyarakat terkait pentingnya menjaga protokol kesehatan seperti memakai masker, menjaga jarak dan menghindari kerumunan. Meskipun begitu ternyata usaha-usaha tersebut masih belum mampu untuk mencegah ataupun menghentikan penularan virus Covid-19 ini [1].

Akibatnya pemerintah harus mengambil langkah tegas untuk menghentikan aktivitas ataupun pergerakan masyarakat agar virus Covid-19 ini tidak semakin meluas dan menelan lebih banyak korban jiwa. Pemerintah memutuskan untuk melaksanakan kebijakan PSBB (Pembatasan Sosial Berskala Besar) di wilayah padat penduduk yaitu Jawa dan Bali yang selanjutnya diberlakukan di seluruh wilayah di Indonesia. Meskipun sempat terjadi berbagai pro dan kontra atas kebijakan ini tetapi jumlah kasus positif Covid-19 mulai menurun setelah diberlakukannya kebijakan PSBB. Hal tersebut membuktikan bahwa kebijakan PSBB cukup efektif untuk diberlakukan di wilayah [2].

Tentunya diperlukan upaya perlindungan lain selain diberlakukannya PSBB dan pemberlakuan protol kesehatan. Setelah diberlakukannya kebijakan PSBB, pemerintah mengambil kebijakan virus Covid-19 ini yaitu vaksinasi. Selama bertahun-tahun vaksin terbukti dapat menurunkan kejadian penyakit menular dalam tubuh manusia melalui mekanisme imunitas tubuh, beberapa vaksin yang telah diresmikan dan dianjurkan oleh pemerintah yaitu vaksin campak dan polio yang telah menyelamatkan ribuan jiwa dari penyakit tersebut. Vaksin Covid-19 sebelumnya telah dikembangkan sejak pandemi Covid-19 ini muncul dan menyerang sebagian besar dunia. Vaksin Covid-19 dikembangkan untuk membentuk imunitas dalam tubuh manusia sehingga diharapkan dapat mempercepat terbentuknya herd immunity yang nantinya akan berdampak pada penurunan jumlah kasus yang terinfeksi [3].

Kabupaten di Jawa Barat yang memiliki tingkat vaksinasi tertinggi yaitu di Kabupaten Sumedang. Sebagian besar dari penduduk di Kabupaten tersebut telah melakukan vaksin dosis pertama dan kedua sehingga termasuk dalam capaian terbaik vaksin Covid-19 di wilayah Jawa Barat. Oleh karena itu, peneliti akan melakukan penelitian untuk mengetahui faktor-faktor yang dapat memengaruhi kesadaran penduduk setempat untuk melakukan vaksinasi dengan metode Multivariate Adaptive Regression Spline (MARS). Terdapat beberapa prediktor yang akan diamati dalam penelitian ini yaitu terkait vaksinasi yang dilakukan, prediktor-prediktor tersebut ialah jenis kelamin, usia, kategori, jenis vaksin, dan dosis vaksin yang diberikan.

Metode statistika yang dapat digunakan untuk menganalisis dan mengklasifikasikan suatu objek dan variabel respon yang bersifat kualitatif atau kategori dengan sejumlah variabel prediktor kontinu atau kategori adalah metode MARS. MARS merupakan pendekatan untuk regresi multivariate nonparametrik yang dikembangkan oleh Friedman. Teknik pemodelan MARS menjadi popular karena tidak mengasumsikan dan tidak menentukan tipe khusus seperti pada hubungan linier, kuadratik, kubik di antara variabel prediktor dan respon. Model MARS difokuskan untuk mengatasi permasalahan dimensi tinggi, memiliki variabel banyak, serta ukuran sampel besar sehingga diperlukan perhitungan yang rumit berdasarkan nilai Generalized Cross Validation (GCV) terkecil. Hasil dari pemodelan ini ialah mengetahui faktor-faktor yang dapat mempengaruhi kesadaran penduduk untuk melakukan vaksin Covid-19 [4].

\section{B. Metodologi Penelitian \\ Teknik Pengumpulan Data}

Data yang digunakan dalam penelitian ini menggunakan data sekunder penduduk Kabupaten Sumedang yang telah melakukan vaksinasi Covid-19 pada tanggal 28 September 2021. Data diperoleh dari Dinas Kesehatan Kabupaten Sumedang.

\section{Vaksin Covid-19}

Vaksin Covid-19 merupakan salah satu upaya pemerintah Indonesia dalam menangani masalah 
Covid-19. Tujuannya untuk menciptakan herd immunity memberikan kekebalan kepada masing-masing individu yang divaksinasi langsung, memberikan kekebalan kepada kelompok apabila banyak orang yang divaksinasi, serta memberi perlindungan kepada orang yang belum mendapat vaksin atau belum menjadi kelompok sasaran vaksinasi [5].

\section{Analisis Deskriptif}

Berdasarkan fase atau tujuan analisisnya, statistika dapat dibedakan atas statistika deskriptif dan statistika inferensial. Statistika deskriptif adalah hal yang berkenaan dengan pengumpulan, pengolahan, penganalisisan, dan penyajian sebagian atau seluruh data (pengamatan) tanpa pengambilan kesimpulan. Analisis ini berguna untuk memberikan gambaran variabel prediktor dan variabel respon yang digunakan [6].

\section{Analisis Regresi}

Analisis regresi merupakan salah satu metode untuk menentukan hubungan sebab-akibat antara satu variabel dengan variabel-variabel yang lain. Pada model regresi, variabel dibedakan menjadi dua bagian, yaitu variabel respon atau biasa juga disebut varibel bergantung (dependent variabel) yang merupakan variabel yang dipengaruhi serta varibel prediktor atau disebut juga variabel bebas (independent variable) yang merupakan variabel yang memengaruhi [6].

\section{Regresi nonparametrik}

Regresi nonparametrik adalah salah satu metode yang digunakan untuk mengestimasi pola hubungan antara variabel respon dan variabel prediktor dimana bentuk kurva regresinya tidak diketahui. Secara umum, regresi nonparametrik dapat dimodelkan sebagai berikut [7]:

Dimana:

$$
y_{i}=f\left(x_{i}\right)+\varepsilon_{i} \quad i=1,2, \ldots, n
$$

$y_{i} \quad$ : variabel respon pada amatan ke- $i$

$f\left(x_{i}\right)$ : fungsi regresi yang tidak diketahui bentuk kurvanya

$\varepsilon_{i} \quad$ : error ke- $i$ yang saling bebas

\section{Multivariate Adaptive Regression Spline (MARS)}

Multivariate Adaptive Regression Spline (MARS) yang merupakan pendekatan untuk regresi multivariate nonparametrik yang dikembangkan oleh Friedman. Model MARS merupakan salah satu metode yang feksibel untuk pemodelan regresi dengan data berdimensi tinggi dengan variabel prediktor $\left(X_{p}\right)$ dimana $3 \leq p \leq 20$ dan ukuran sampel $50 \leq n \leq 1000$. Model MARS adalah kombinasi yang kompleks antara metode spline dengan Recursive Partitioning Regression (RPR) untuk menghasilkan estimasi fungsi regresi yang kontinu. Perhitungan komputasi sangat diperlukan dalam pengolahan data, karena akan selalu memperoleh hasil yang sesuai dengan algoritmanya. RPR merupakan salah satu dari program komputasi yang memiliki keunggulan dalam mengolah data yang berdimensi tinggi. Pendekatan RPR dimulai dengan menghasilkan model yang memiliki sejumlah fungsi basis untuk meningkatkan kecocokan model. RPR merupakan suatu metode nonparametrik yang dapat dipandang sebagai suatu prosedur regresi stepwise untuk mengaproksimasi fungsi yang tidak diketahui $f(x)$. Persamaan model MARS dapat ditulis sebagai berikut [8]:

dimana:

$$
f(x)=a_{0}+a_{1} B F_{1}+a_{2} B F_{2}+\cdots+a_{M} B F_{M}
$$

$f(x)$ : variabel respon

$a_{0} \quad$ : konstanta

$a_{M} \quad$ : koefisien untuk basis fungsi ke- $M$

$B F_{M}$ : basis fungsi ke- $M$

\section{Pemilihan Model Terbaik MARS}

Model terbaik pada MARS ditentukan berdasarkan kriteria Generalized Cross Validation (GCV) minimum yang didefinisikan sebagai berikut [8]: 
Dimana:

$$
\begin{gathered}
\operatorname{GCV}(M)=\frac{\frac{1}{n} \sum_{i=1}^{n}\left[y_{i}-\hat{f}_{M}\left(x_{i}\right)\right]^{2}}{\left[1-\frac{C(M)^{2}}{n}\right]} \\
M S E=\frac{1}{n} \sum_{i=1}^{n}\left[y_{i}-\hat{f}_{M}\left(x_{i}\right)\right]^{2}
\end{gathered}
$$

$$
\begin{array}{ll}
y_{i} & : \text { variabel respon ke- } i \\
M & : \text { jumlah fungsi basis } \\
x_{i} & : \text { variabel prediktor ke- } i \\
n & : \text { banyaknya pengamatan } \\
C(M) & : \text { Trace }\left[B\left(B^{T} B\right)-1 B^{T}\right]+1
\end{array}
$$

\begin{tabular}{|c|c|c|c|c|c|c|c|c|c|c|c|c|c|c|c|c|c|c|c|c|}
\hline \multicolumn{21}{|c|}{ Proporsi Variabel Berdasarkan Nilai Minimum dan Maksimum } \\
\hline \multirow{2}{*}{ Variabel } & \multirow{2}{*}{$\mathrm{N}$} & \multicolumn{3}{|c|}{ Frekuensi } & \multicolumn{4}{|c|}{ Frekuensi } & \multicolumn{3}{|c|}{ Frekuensi } & \multicolumn{4}{|c|}{ Frekuensi } & \multicolumn{3}{|c|}{ Freklensi } & \multicolumn{2}{|c|}{ Frektuensi } \\
\hline & & \begin{tabular}{l|l|l}
1 & $\%$ \\
\end{tabular} & 2 & $\%$ & 15 tahl & & 65 tahun & & 1 & $\%$ & $5 \%$ & 1 & $\%$ & $2 \%$ & 1 & $\%$ & 2 & & & $30,11 \%$ \\
\hline Jenis Kelamin & & $16654 \%$ & \%143. & $346 \%$ & & & & & & & & & & & & & & & & \\
\hline Usia & 309 & & & & 4 & $1 \%$ & 2 & $1 \%$ & & & & & & & & & & & & \\
\hline Kategori & 309 & & & & & & & & & $83 \%$ & & & & & & & & & & \\
\hline Jenis Vaksin & 309 & & & & & & & & & & & & $92 \%$ & $248 \%$ & & & & & & \\
\hline Dosis & 309 & & & & & & & & & & & & & & & $7 \%$ & & $3 \%$ & & \\
\hline Tingkat Pencapaian I & 309 & & & & & & & & & & & & & & & & & & 32 & 253 \\
\hline
\end{tabular}

\section{Hasil Penelitian dan Pembahasan}

\section{Analisis Deskriptif}

Analisis deskriptif berguna untuk menganalisis data dengan cara mendeskripsikan atau menggambarkan data yang telah terkumpul tanpa bermaksud membuat kesimpulan.

Tabel 1. Analisis Deskriptif

Dari hasil analisis deskriptif pada tabel diatas, didapatkan informasi sebagai berikut:

1. Variabel jenis kelamin memiliki minimum sebesar 1 yang artinya tingkat pencapaian vaksin terendah berada pada kode jenis kelamin 1 dengan proporsi 166 jiwa dan tingkat pencapaian tertinggi berada pada kode jenis kelamin 2 dengan proporsi 143 jiwa.

2. Variabel usia memiliki minimum sebesar 15 yang artinya tingkat pencapaian vaksin terendah berada pada usia 15 dengan proporsi 4 jiwa dan tingkat pencapaian tertinggi berada pada usia dengan proporsi 2 jiwa.

3. Variabel kategori memiliki minimum sebesar 1 yang artinya tingkat pencapaian vaksin terendah berada pada kode kategori 1 dengan proporsi 257 jiwa dan tingkat pencapaian tertinggi berada pada kode kategori 5 dengan proporsi 6 jiwa.

4. Variabel jenis vaksin memiliki minimum sebesar 1 yang artinya tingkat pencapaian vaksin terendah berada pada jenis vaksin 1 dengan proporsi 285 jiwa dan tingkat pencapaian tertinggi berada pada jenis vaksin 2 dengan proporsi 28 jiwa.

5. Variabel dosis vaksin memiliki minimum sebesar 1 yang artinya tingkat pencapaian vaksin terendah berada pada dosis 1 dengan proporsi 301 jiwa dan tingkat pencapaian tertinggi berada pada dosis 2 dengan proporsi 8 jiwa.

6. Tingkat pencapaian vaksin memiliki minimum sebesar 0,57 yang artinya tingkat pencapaian vaksin terendah berada pada tingkat pencapaian vaksin sebesar 0,57 dengan proporsi 32 jiwa dan tingkat pencapaian tertinggi berada pada 30,11 dengan proporsi 253 jiwa.

\section{Uji Asumsi Model Regresi}

Sebelum dilakukan analisis dengan menggunakan metode MARS dilakukan pengujian asumsi regresi klasik terlebih dahulu. Apabila memenuhi asumsi regresi klasik maka termasuk model regresi parametrik, dan sebaliknya apabila terdapat salah satu uji tidak memenuhi asumsi regresi klasik maka termasuk model regresi nonparametrik dan dapat menggunakan metode MARS. 


\section{Uji Normalitas}

Uji normalitas digunakan untuk mengetahui apakah populasi data berdistribusi normal atau tidak. Pengujian normalisasi dilakukan dengan metode Kolmogorov-Smirnov Test pada program SPSS 25 For Windows.

Tabel 2. Hasil Uji Normalitas

\begin{tabular}{|ll|r|}
\hline \multicolumn{2}{|c|}{ One-Sample Kolmogorov-Smirnov Test } \\
\hline $\mathrm{N}$ & $\begin{array}{c}\text { Unstandardized } \\
\text { Residual }\end{array}$ \\
\hline Normal Parameters ${ }^{\mathrm{a}, \mathrm{b}}$ & Mean & 309 \\
& Std. Deviation & .0000000 \\
Most Extreme & Absolute & .55529840 \\
Differences & Positive & .345 \\
& Negative & -.345 \\
Kolmogorov-Smirnov Z & 6.062 \\
Asymp. Sig. (2-tailed) & .000 \\
\hline
\end{tabular}
a. Test distribution is Normal.
b. Calculated from data.

Hasil pengujian normalitas dapat diketahui berdasarkan nilai Asymp. Sig. (2-tailed) dan nilai Kolmogorov-Smirnov. Pada Unstandardized Residual nilai signifikansi (Asymp. Sig) 0,000. Nilai tersebut lebih kecil dari nilai signifikansi 0,05 maka dapat disimpulkan bahwa data dalam model regresi ini tidak berdistribusi normal.

\section{Uji Heteroskedastisitas}

Uji Heteroskedastisitas bertujuan untuk menguji apakah dalam model regresi terjadi ketidaksamaan variansi dari residual satu pengamatan ke pengamatan lain. Jika variansi dari residual satu pengamatan ke pengamatan lain tetap, maka disebut Homoskedastisitas dan jika berbeda disebut Heteroskedastisitas. Uji statistik yang dapat digunakan adalah uji Glejser.

Tabel 3. Hasil Uji Heteroskedastisitas

Coefficients $^{2}$

\begin{tabular}{|c|c|c|c|c|c|c|}
\hline & & \multicolumn{2}{|c|}{$\begin{array}{l}\text { Unstandardized } \\
\text { Coefficients }\end{array}$} & \multirow{2}{*}{$\begin{array}{c}\text { Standardized } \\
\text { Coefficients }\end{array}$} & \multirow[b]{2}{*}{$\mathrm{T}$} & \multirow[b]{2}{*}{ Sig. } \\
\hline \multicolumn{2}{|c|}{ Model } & $\mathrm{B}$ & Std. Error & & & \\
\hline \multirow[t]{6}{*}{1} & (Constant) & -10.106 & .627 & & -16.123 & .000 \\
\hline & Jenis Kelamin & -.361 & .159 & -.047 & -2.264 & .024 \\
\hline & Usia & .035 & .008 & .114 & 4.269 & .000 \\
\hline & Kategori & 3.043 & .115 & .686 & 26.365 & .000 \\
\hline & Jenis Vaksin & 6.376 & .379 & .445 & 16.836 & .000 \\
\hline & Dosis & .867 & .606 & .036 & 1.430 & .154 \\
\hline
\end{tabular}

Berdasarkan hasil tabel diatas dapat disimpulkan bahwa hasil uji heterokedastisitas memiliki gejala heterekedastisitas karena sebagian besar tingkat signifikasi $<0,05$ yang artinya tidak ada kesamaan antara variabel jenis kelamin, usia, kategori, jenis vaksin, dan dosis dalam mempengaruhi tingkat pencapaian vaksin.

\section{Uji Autokorelasi}

Untuk mendiagnosis adanya autokorelasi dalam suatu model regresi dilakukan pengujian terhadap nilai uji Durbin-Watson (uji DW). 
Tabel 4. Hasil Uji Autokorelasi

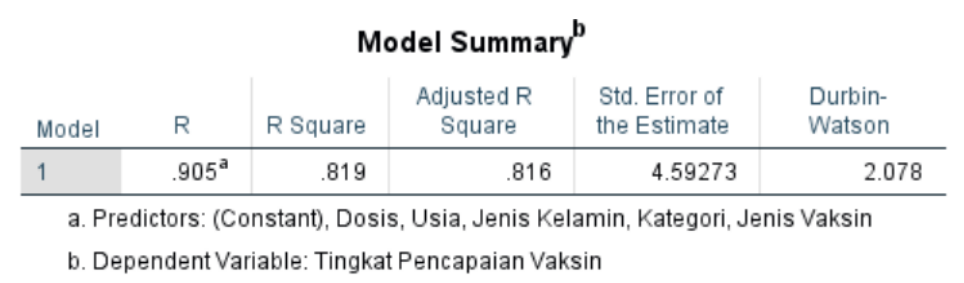

Berdasarkan hasil tabel diatas terlihat bahwa nilai Durbin-Watson sebesar 2, 078. Jadi karena 1, $55<\mathbf{2 , 0 7 8}<\mathbf{2 , 4 6}$ maka model tersebut tidak ada autokorelasi.

\section{Model MARS Terbaik}

Model MARS terbaik diperoleh dari hasil kombinasi $B F=15, M I=3$, dan $M O=1$ dengan nilai $G C V$ minimum 0,00637 . Bentuk model yang diperoleh adalah sebagai berikut:

$$
\begin{aligned}
Y=3,95002- & 3,38001 \times B F_{1}+26,16 \times B F_{2}-19,27 \times B F_{3}+4,92501 \times B F_{4} \\
& +1,5325 \times B F_{6}-0,86226 \times B F_{7}+0,859498 \times B F_{8}+0,862245 \times B F_{9} \\
& -1,71828 \times B F_{10}+0,858777 \times B F_{13}+1,72336 \times B F_{15}
\end{aligned}
$$

Basis fungsi (BF) dalam model sebagai berikut:

$$
\begin{gathered}
\mathrm{BF}_{1}=\max \left(0, \mathrm{X}_{3}-2\right) ; \\
\mathrm{BF}_{2}=\max \left(0,2-\mathrm{X}_{3}\right) ; \\
\mathrm{BF}_{3}=\max \left(0, \mathrm{X}_{5}-1\right) \times \mathrm{BF}_{2} ; \\
\mathrm{BF}_{4}=\max \left(0, \mathrm{X}_{3}-3\right) ; \\
\mathrm{BF}_{5}=\max \left(0,3-\mathrm{X}_{3}\right) ; \\
\mathrm{BF}_{6}=\max \left(0, \mathrm{X}_{4}-1\right) \times \mathrm{BF}_{1} ; \\
\mathrm{BF}_{7}=\max \left(0, \mathrm{X}_{4}-1\right) \times \mathrm{BF}_{5} ; \\
\mathrm{BF}_{8}=\max \left(0, \mathrm{X}_{2}-16\right) \times \mathrm{BF}_{7} ; \\
\mathrm{BF}_{9}=\max \left(0,16-\mathrm{X}_{2}\right) \times \mathrm{BF}_{7} ; \\
\mathrm{BF}_{10}=\max \left(0, \mathrm{X}_{2}-17\right) \times \mathrm{BF}_{7} ; \\
\mathrm{BF}_{13}=\max \left(0, \mathrm{X}_{2}-18\right) \times \mathrm{BF}_{7} ; \\
\mathrm{BF}_{15}=\max \left(0, \mathrm{X}_{4}-1\right) \times \mathrm{BF}_{2} ;
\end{gathered}
$$

Dari model terbaik yang dihasilkan, dapat disimpulkan bahwa variabel-variabel prediktor yang mempengaruhi tingkat pencapaian vaksin menggunakan model MARS dengan nilai GCV terkecil adalah usia $\left(X_{2}\right)$, kategori $\left(X_{3}\right)$, jenis vaksin $\left(X_{4}\right)$, dan dosis $\left(X_{5}\right)$.

Variabel prediktor yang berpengaruh pada model MARS yaitu karena variabel kategori $\left(X_{3}\right)$ memiliki tingkat kepentingan sebesar $100 \%$ terhadap variabel respon, variabel dosis $\left(X_{5}\right)$ memiliki tingkat kepentingan sebesar $14,21 \%$ terhadap variabel respon, variabel jenis vaksin $\left(X_{4}\right)$ memiliki tingkat kepentingan sebesar 3,16\% terhadap variabel respon, dan variabel usia $\left(X_{2}\right)$ memiliki tingkat kepentingan sebesar $0,53 \%$ terhadap variabel respon. Tingkat kepentingan dari masing-masing variabel prediktor yang berpengaruh terdapat pada tabel berikut:

Tabel 5. Skor Variable Importance Model MARS Terbaik

\begin{tabular}{|c|c|}
\hline Variabel & Skor Variable Importance \\
\hline Kategori $\left(X_{3}\right)$ & $100 \%$ \\
\hline Dosis $\left(X_{5}\right)$ & $14,21 \%$ \\
\hline Jenis Vaksin $\left(X_{4}\right)$ & $3,16 \%$ \\
\hline Usia $\left(X_{2}\right)$ & $0,53 \%$ \\
\hline
\end{tabular}

\section{Pengujian Signifikansi Model MARS}

Pengujian signifikansi model MARS dilakukan pengujian mengecek signifikan parameter untuk mengevaluasi kecocokan model. 


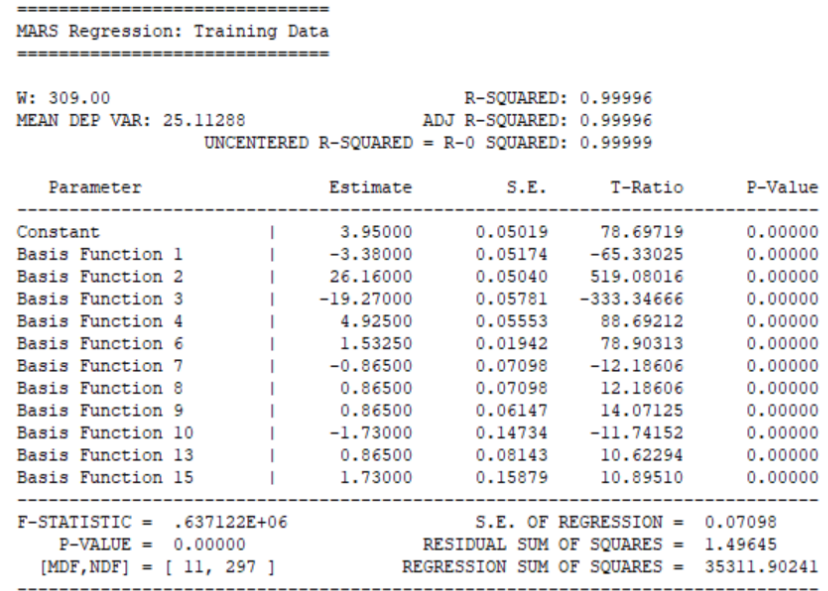

Gambar 1. Output Pemodelan Data Menggunakan Metode MARS

\section{Uji Simultan}

Uji simultan dilakukan dengan hipotesis sebagai berikut:

$$
H_{0}: \alpha_{0}=\alpha_{1}=\alpha_{2}=\alpha_{3}=\alpha_{4}=\alpha_{6}=\alpha_{7}=\alpha_{8}=\alpha_{9}=\quad \alpha_{10}=\alpha_{13}=\alpha_{15}=0
$$

(model tidak signifikan) signifikan)

$H_{1}$ : minimal terdapat satu $\propto_{M} \neq 0 ; m=0,1,2,3,4,6,7,8,9,10,13$, dan 15 (model

Berdasarkan gambar 1 diperoleh $p$-value sebesar 0.00000. Karena $p-$ value $<0,05$ maka dapat disimpulkan bahwa model MARS yang dimiliki adalah model yang signifikan.

\section{Uji Parsial}

Uji parsial dilakukan dengan hipotesis sebagai berikut:

$H_{0}: \alpha_{\mathrm{M}}=0$ (koefisien $\propto_{M}$ tidak berpengaruh terhadap model) model)

$H_{1}: \alpha_{\mathrm{M}} \neq 0 ; M=0,1,2,3,4,6,7,8,9,10,13$, dan 15 (koefisien $\propto_{M}$ berpengaruh terhadap

Karena seluruh estimator parameter berdasarkan gambar 1 yaitu $\alpha_{0}, \alpha_{1}, \alpha_{2}, \alpha_{3}, \alpha_{4}, \alpha_{6}, \alpha_{7}, \alpha_{8}, \alpha_{9}, \alpha_{10} \alpha_{13}$, dan $\alpha_{15}$ mempunyai nilai $P-$ value $<0.05$ maka untuk seluruh estimator parameter dapat disimpulkan bahwa konstanta dan koefisien fungsi basis $0,1,2,3,4,6,7,8,9,10,13$, dan 15 mempunyai pengaruh yang signifikan terhadap model.

\section{Interpretasi Model MARS}

Interpretasi model MARS adalah sebagai berikut:

1. $B F_{1}=\max \left(0, X_{3}-2\right)$

Dengan koefisien $-3,38001$

Artinya bahwa setiap kenaikan BF1 akan menurunkan tingkat pencapaian vaksin sebesar 3,38001 jika nilai variabel $X_{3}$ memiliki nilai yang lebih besar dari 2 .

2. $B F_{2}=\max \left(0,2-X_{3}\right)$

Dengan koefisien 26,16

Artinya bahwa setiap kenaikan BF2 akan meningkatkan tingkat pencapaian vaksin sebesar 26,16 jika nilai variabel $X_{3}$ memiliki nilai yang lebih kecil dari 2 .

3. $B F_{3}=\max \left(0, X_{5}-1\right) \times B F_{2}$

Dengan koefisien $-19,27$

Artinya bahwa setiap kenaikan BF3 akan menurunkan tingkat pencapaian vaksin sebesar 19,27 jika nilai variabel $X_{5}$ memiliki nilai yang lebih besar dari 1 dan nilai varibel $X_{3}$ lebih kecil dari 2.

4. $B F_{4}=\max \left(0, X_{3}-3\right)$

Dengan koefisien 4,92501

Artinya bahwa setiap kenaikan BF4 akan meningkatkan tingkat pencapaian vaksin 
sebesar 4,92501 jika nilai variabel $X_{3}$ memiliki nilai yang lebih besar dari 3 .

5. $B F_{6}=\max \left(0, X_{4}-1\right) \times B F_{1}$

Dengan koefisien 1,5325

Artinya bahwa setiap kenaikan BF6 akan meningkatkan tingkat pencapaian vaksin sebesar 1,5325 jika nilai variabel $X_{4}$ memiliki nilai yang lebih besar dari 1 dan nilai variabel $X_{3}$ lebih besar dari 2 .

6. $B F_{7}=\max \left(0, X_{4}-1\right) \times B F_{5}$

Dengan koefisien $-0,86226$

Artinya bahwa setiap kenaikan BF7 akan menurunkan tingkat pencapaian vaksin sebesar $-0,86226$ jika nilai variabel $X_{4}$ memiliki nilai yang lebih besar dari 1 dan nilai variabel $X_{3}$ lebih kecil dari 3 .

7. $B F_{8}=\max \left(0, X_{2}-16\right) \times B F_{7}$

Dengan koefisien 0,859498

Artinya bahwa setiap kenaikan BF8 akan meningkatkan tingkat pencapaian vaksin sebesar 0,859498 jika nilai variabel $X_{2}$ memiliki nilai yang lebih besar dari 16 dan nilai variabel $X_{4}$ lebih besar dari 1 .

8. $B F_{9}=\max \left(0,16-X_{2}\right) \times B F_{7}$

Dengan koefisien 0,862245

Artinya bahwa setiap kenaikan BF9 akan meningkatkan tingkat pencapaian vaksin sebesar 0,862245 jika nilai variabel $X_{2}$ memiliki nilai yang lebih kecil dari 16 dan nilai variabel $X_{4}$ lebih besar dari 1 .

9. $B F_{10}=\max \left(0, X_{2}-17\right) \times B F_{7}$

Dengan koefisien $-1,71828$

Artinya bahwa setiap kenaikan BF10 akan meningkatkan tingkat pencapaian vaksin sebesar $-1,71828$ jika nilai variabel $X_{2}$ memiliki nilai yang lebih besar dari 17 dan nilai variabel $X_{4}$ lebih besar dari 1 .

10. $B F_{13}=\max \left(0, X_{2}-18\right) \times B F_{7}$

Dengan koefisien 0,858777

Artinya bahwa setiap kenaikan BF13 akan meningkatkan tingkat pencapaian vaksin sebesar 0,858777 jika nilai variabel $X_{2}$ memiliki nilai yang lebih besar dari 18 dan nilai variabel $X_{4}$ lebih besar dari 1 .

11. $B F_{15}=\max \left(0, X_{4}-1\right) \times B F_{2}$

Dengan koefisien 1,72336

Artinya bahwa setiap kenaikan BF15 akan meningkatkan tingkat pencapaian vaksin sebesar 1,72336 jika nilai variabel $X_{4}$ memiliki nilai yang lebih besar dari 1 dan nilai variabel $X_{3}$ lebih besar dari 2 .

\section{Kesimpulan}

Berdasarkan hasil dari pembahasan di atas, maka dapat diperoleh kesimpulan sebagai berikut:

1. Model MARS terbaik dari 36 model yang terbentuk dihasilkan model terbaiknya yaitu dari kombinasi $\mathrm{BF}=15, \mathrm{MI}=3$, dan $\mathrm{MO}=1$ karena memiliki nilai $\mathrm{GCV}$ minimum sebesar 0,00637 dengan persamaan model sebagai berikut:

$$
\begin{aligned}
& \mathrm{BF}_{1}=\max \left(0, \mathrm{X}_{3}-2\right) ; \\
& \mathrm{BF}_{2}=\max \left(0,2-\mathrm{X}_{3}\right) ; \\
& \mathrm{BF}_{3}=\max \left(0, \mathrm{X}_{5}-1\right) \times \mathrm{BF}_{2} ; \\
& \mathrm{BF}_{4}=\max \left(0, \mathrm{X}_{3}-3\right) ; \\
& \mathrm{BF}_{5}=\max \left(0,3-\mathrm{X}_{3}\right) ; \\
& \mathrm{BF}_{6}=\max \left(0, \mathrm{X}_{4}-1\right) \times \mathrm{BF}_{1} ; \\
& \mathrm{BF}_{7}=\max \left(0, \mathrm{X}_{4}-1\right) \times \mathrm{BF}_{5} ; \\
& \mathrm{BF}_{8}=\max \left(0, \mathrm{X}_{2}-16\right) \times \mathrm{BF}_{7} ; \\
& \mathrm{BF}_{9}=\max \left(0,16-\mathrm{X}_{2}\right) \times \mathrm{BF}_{7} ; \\
& \mathrm{BF}_{10}=\max \left(0, \mathrm{X}_{2}-17\right) \times \mathrm{BF}_{7} ; \\
& \mathrm{BF}_{13}=\max \left(0, \mathrm{X}_{2}-18\right) \times \mathrm{BF}_{7} ;
\end{aligned}
$$




$$
\begin{aligned}
& \mathrm{BF}_{15}=\max \left(0, \mathrm{X}_{4}-1\right) \times \mathrm{BF}_{2} ; \\
& Y=3,95002- 3,38001 \times B F_{1}+26,16 \times B F_{2}-19,27 \times B F_{3}+4,92501 \times B F_{4} \\
&+1,5325 \times B F_{6}-0,86226 \times B F_{7}+0,859498 \times B F_{8} \\
&+0,862245 \times B F_{9}-1,71828 \times B F_{10}+0,858777 \times B F_{13} \\
&+1,72336 \times B F_{15}
\end{aligned}
$$

2. Variabel yang memiliki pengaruh paling dominan terhadap tingkat pencapaian vaksin Covid-19 adalah variabel kategori $\left(X_{3}\right)$ dengan skor variable importance sebesar 100\%, variabel dosis $\left(X_{5}\right)$ sebesar 14,21\%, variabel jenis vaksin $\left(X_{4}\right)$ sebesar $3,16 \%$, dan variabel usia $\left(X_{2}\right)$ sebesar $0,53 \%$.

\section{Acknowledge}

Terima kasih disampaikan kepada Bapak Abdul Kudus, M.Si., Ph.D. selaku Dekan Fakultas Matematika dan Ilmu Pengetahuan Alam, Universitas Islam Bandung, Bapak Gani Gunawan, S.Si., M.Si. dan Ibu Dr. Yani Ramdani, Dra., M.Pd. selaku pembimbing yang senantiasa memberikan bimbingan, arahan, dan motivasi kepada penulis selama proses penyusunan dan penulisan artikel ini.

\section{Daftar Pustaka}

[1] A. Makmun dan S. F. Hazhiyah, "Tinjauan Terkait Pengembangan Vaksin Covid-19," Molucca Medica, vol. 13, no. 2, pp. 52-59, 2020.

[2] I. Wahidah, M. A. Septiadi, M. C. A. Rafqie, N. F. S. Hartono dan R. Athallah, "Pandemik Covid-19: Analisis Perencanaan Pemerintah dan Masyarakat dalam Berbagai Upaya," Jurnal Manajemen dan Organisasi (JMO), vol. 11, no. 3, pp. 179-188, 2020.

[3] Y. A. Rahman, "Vaksinasi Massal Covid-19 Sebagai Sebuah Upaya Masyarakat dalam Melaksanakan Kepatuhan Hukum (Obedience Law)," Khazanah Hukum, vol. 3, no. 2, pp. 80-86, 2021.

[4] S. Anam, "Ketepatan Klasifikasi Dengan Menggunakan Metode Multivariate Adaptive Regression Spline (MARS) Pada Data Kelompok Rumah Tangga Kabupaten Cilacap," Semarang, 2017.

[5] Z. L. Argista, "Persepsi Masyarakat Terhadap Vaksin Covid-19 di Sumatera Selatan," Sumatera, 2021.

[6] A. P. Raditya, "Penerapan Metode Multivariate Adaptive Regression Spline (MARS) Dengan Estimator Nadaraya-Watson Fungsi Kernel Gaussian," Yogyakarta, 2018.

[7] S. Zurimi dan D. , "Analisis Model Aplikatif Multivariate Adaptive Regression Spline ( MARS) Terhadap Klasifikasi Faktor yang Mempengaruhi Masa Studi Mahasiswa FKIP Universitas Darussalam Ambon,” Jurnal Simetrik, vol. 9, no. 2, pp. 250-255, 2019.

[8] B. W. Otok, "Pendekatan Multivariate Adaptive Regression Splines (MARS) pada Pemodelan Penduduk Miskin di Indonesia Tahun 2008-2012," dalam Prosiding Seminar Nasional Matematika, 2014. 